\title{
Wheezing in Children with Sickle Cell Disease
}

\author{
Jeffrey A. Glassberg, MD, MA ${ }^{1}$, Robert Strunk, MD $^{2}$, and Michael R. DeBaun, MD, MPH ${ }^{3}$ \\ Jeffrey A. Glassberg: jeffreyglassberg@gmail.com \\ ${ }^{1}$ Assistant Professor of Emergency Medicine, Hematology and Medical Oncology (pending), \\ Mount Sinai School of Medicine, 1 Gustave Levy Place Box 1620, New York, NY 10029, Phone: \\ (212)-824-8056, Fax: (212) 426-1946 \\ 2Professor of Pediatrics, Washington University School of Medicine in St. Louis, 1 Children's \\ Place, Office 2515, St. Louis, MO 63110, Phone 314-4542694 \\ ${ }^{3}$ Professor of Pediatrics and Medicine, JC Peterson Endowed Chair in Pediatrics, Vice Chair for \\ Clinical Research, Pediatrics, Director, Vanderbilt-Meharry Center of Excellence in Sickle Cell \\ Disease, Monroe Carell Jr. Children's Hospital at Vanderbilt, 2200 Children's Way, Room 11206 \\ DOT, Nashville, TN 37232-9000
}

\begin{abstract}
Purpose of review-The purpose of this article is to provide a comprehensive review of wheezing in sickle cell disease (SCD) including epidemiology, pathophysiology, associations between wheezing and SCD morbidity and finally the clinical approach to evaluation and management of individuals with SCD who wheeze.
\end{abstract}

\begin{abstract}
Recent findings-Wheezing is common in SCD and in some individuals represents an intrinsic component of SCD related lung disease rather than asthma. Emerging data suggest that regardless of the etiology, individuals with SCD and with recurrent wheezing are at increased risk for subsequent morbidity and premature mortality. We believe Individuals that acutely wheeze and have respiratory symptoms should be managed with a beta agonist and short term treatment of oral steroids, typically less than 3 days to attenuate rebound vaso-occlusive disease. For those that wheeze and have a history or examination associated with atopy, we consider asthma treatment and monitoring per NHLBI asthma guidelines.
\end{abstract}

Summary-Wheezing in SCD should be treated aggressively in both the acute setting and with controller medications. Prospective SCD-specific clinical trials will be necessary to address whether anti-inflammatory asthma therapies (leukotriene antagonists, inhaled corticosteroids) can safely mitigate the sequelae of wheezing in SCD.

\section{Keywords}

Sickle cell; wheezing; asthma

Correspondence to: Michael R. DeBaun.

Conflicts of Interest:

The authors have no conflicts of interest to report. 


\section{i. Introduction}

Wheezing is defined by the American Thoracic Society as high-pitched continuous adventitial lung sounds, presumed to be caused by turbulent air flow through narrowed small and medium size airways in the lung. ${ }^{1}$ While wheeze is a symptom most closely associated with a diagnosis of asthma, there are many other causes; and for individuals with sickle cell disease (SCD), emerging data suggest that wheezing may be a pulmonary manifestation of SCD. The purpose of this article is to provide a comprehensive review of wheezing in SCD including epidemiology, pathophysiology, associations between wheezing and SCD morbidity and finally the clinical approach to evaluation and management of individuals with SCD who wheeze.

SCD is an inherited disorder of hemoglobin that affects approximately 100,000 Americans. ${ }^{2}$ SCD follows an autosomal recessive inheritance pattern and refers to a family of genetic mutations that affect the beta globin gene. The most common mutation in SCD involves substitution of glutamine for valine at codon six of the beta globin gene. Instead of wild type hemoglobin (referred to as hemoglobin A), this mutation produces hemoglobin $\mathrm{S}$ which forms rigid polymers under deoxygenated conditions (thus giving red cells their characteristic sickled shape). Individuals who are homozygous for this mutation have hemoglobin SS (widely referred to as sickle cell anemia) however a number of other mutations of beta globin have been described. The umbrella term "sickle cell disease" refers to genotypes in which both hemoglobin genes carry a mutation at least one of which is hemoglobin S. For individuals living with the disease, the process of red cell sickling under deoxygenated conditions contributes to a complex state of altered blood rheology. The lung is the only organ capable of reversing the polymerization of hemoglobin and decreasing the proportion of red blood cells that are sickled, the cells that initiate vascular injury and the cascade of systemic complications. Thus, any pulmonary disease occurring in SCD would be expected to significantly compromise individuals with SCD because of attenuated ability to reverse red blood cell polymerization.

Clinical and pre-clinical data strongly suggest that lung disease increases SCD related morbidity and mortality. More specifically children and adults with asthma have an increased rate of vaso-occlusive pain episodes, acute chest syndrome (ACS) episodes, and premature mortality when compared to those without asthma. However, the diagnosis of asthma is challenging, particularly among children with a pre-existing chronic disease that has many asthma symptoms (wheezing, coughing, shortness of breath) and clinical risk factors (elevated IgE levels, lower airway obstruction, airway hyper responsiveness and bronchodilator response) associated with asthma.

Management of asthma in individuals with SCD should be treated in accordance with National Institutes of Health National Asthma Education and Prevention Program recommendations. ${ }^{3}$ Unfortunately optimal management is less clear for individuals with SCD who do not meet criteria for a diagnosis of asthma but manifest occasional or recurrent wheezing. Given the clinical overlap between symptoms of SCD (dyspnea on exertion, chest tightness, and more recently observed wheezing) and asthma, making a clear diagnosis of asthma is more complex than in the general population. The focus of this review is to 
summarize the basic and clinical data supporting wheezing as a harbinger for future SCD related morbidity.

\section{ii. Methods}

This review was not considered human subjects research. A systematic search strategy was employed for pubmed, ovid, and the Cochrane library databases. Search terms included "sickle AND asthma" and "sickle AND wheeze." In addition to results of systematic searches, relevant citations that did not come up on the initial search but were found in the reference sections of articles pulled from the initial search were also included. Search results were downloaded in PDF form and reviewed individually by the lead author. Summaries of all articles were compiled into tabular format for all authors to review.

\section{iii. Epidemiology}

Prevalence estimates for wheezing in SCD vary with study methodology. Retrospective cohorts typically report lower rates of wheezing ${ }^{4-9}$ with estimates ranging from $3.6 \%$ to $18.7 \%$. Many of the retrospective estimates were based on specialty practices that do not reflect the full spectrum of either asthma or sickle cell disease. Higher estimates of wheezing are likely due to selection bias (some cohorts reviewed charts during episodes of ACS). Five prospective studies document the prevalence of wheezing in individuals with SCD (table 1). Knight-Madden et al. (2005) $)^{10,11}$ and Jacob et al. (2010) ${ }^{12}$ used modified versions of the International Study of Asthma and Allergies in Childhood (ISAAC) questionnaire in separate cohorts of children with SCD and found the prevalence of wheezing to range from $29 \%$ to $41 \%$. A separate pediatric cohort by Field et al. (2011) ${ }^{13}$ used the American Thoracic Society Division of Lung Diseases (ATS-DLD) survey and found the prevalence of wheezing to be $51 \%$. Participants were not selected based on the presence of asthma; however all three participating sites had sickle cell disease programs with an extensive influence of asthma experts.

More recently in a prospective cohort of 114 adults from St. Louis with SCD, Cohen and colleagues reported that the prevalence of recurrent severe wheezing was $64 \% .{ }^{14}$ Of particular interest in the St. Louis cohort, the prevalence of various respiratory symptoms was stratified by those who did and did not carry a physician diagnosis of asthma. Of adults who reported wheezing, only 38\% carried a diagnosis of asthma. Those who carried a diagnosis of asthma were more likely to have other clinical features classically associated with atopy and asthma including eosinophilia, elevated serum IgE, eczema, allergic rhinitis and a family history of atopy. Wheezing, especially wheezing without colds, was more likely to occur in individuals with an asthma diagnosis; however substantial proportions of individuals without asthma reported wheezing with exercise (30\%), without colds (18\%), during colds $(51 \%)$ and recurrent severe wheezing $(20 \%)$. These results in children and adults with SCD strongly suggest that regardless of a diagnosis of asthma, wheezing symptoms are common. ${ }^{15}$ 


\section{iv. Etiology of wheezing due to SCD}

Based on pre-clinical and clinical findings, the etiology of wheezing due to SCD appears to be inflammatory; however, the underlying factors that contribute to this inflammation are still poorly understood. Murine models of SCD lungs show several important differences in comparison to control mice. Even under normoxic conditions lungs of SCD mice demonstrate higher levels of xanthine oxidase (a marker of vascular injury), nitrotyrosine (a marker of nitric oxide (NO) scavenging by reactive oxygen species) and lower cGMP (a marker of NO biological activity) than controls. ${ }^{16}$ In another study, lung sections of SCD mice demonstrated increased inflammatory cell counts (eosinophils) and elevated IgE levels in comparison to control mice. SCD mice were more sensitive to experimental induction of asthma with ovalbumin and exposure to hypoxia also dramatically increased markers of vascular injury and perturbations of NO production in SCD mice in comparison to control. Taken together these data suggest that even under normal conditions, the lungs of SCD mice experience varying degrees of injury that may contribute to alterations in pulmonary physiology. ${ }^{17}$

\section{v. Associations between wheezing and SCD morbidity}

A physician diagnosis of asthma is well established as an important risk factor for increased SCD morbidity (pain, ACS and stroke) and premature mortality. $6,8,10,18-28$ The few studies that have directly addressed the effects of wheezing in SCD morbidity suggest that the adverse associations between asthma and SCD complications may be in part due to collinearity with wheezing. We propose a conceptual model whereby wheezing, a sign of severe narrowing of small airways, results in regional hypoxia within the lung thereby limiting the lung's ability to reverse red cell sickling and promoting increased systemic complications of SCD (figure 1).

In a retrospective cohort of ED visits for $\mathrm{SCD}$, our group demonstrated that a physician diagnosis of asthma was associated with an adjusted $44 \%$ increase in ED visits for pain (95\% CI 2-104\%); however, individuals who had at least one episode of wheezing documented in their medical record (at any time, not necessarily during an ED visit) had a $118 \%$ increase in ED visits for pain (95\%CI 56-205\%). Similar effects were observed for acute chest syndrome. A history of wheezing was associated with a $158 \%$ increase in the rate of ACS, whereas for asthma, a statistically significant increase was not found (rate ratio $1.00,95 \%$ CI $0.41-2.47){ }^{7}$

In two prospective cohorts, a diagnosis of asthma (often considered a lifelong condition) without having active respiratory symptoms, was not associated with substantial increases in SCD morbidity. ${ }^{11,29}$ Cohen and colleagues, in a cohort of 114 adults with SCD, used multivariable models to estimate adjusted rate ratios for the effects of asthma and recurrent severe wheezing on pain and ACS. ${ }^{14}$ Recurrent severe wheezing, but not a doctor diagnosis of asthma, was associated with a doubling in the rates of pain (RR 2.0 95\%CI 1.2-3.4 for wheezing vs. 0.99 95\%CI 0.6-1.7 for asthma) and ACS (RR 2.1 95\%CI 1.1-4.0 for wheezing vs. $1.395 \%$ CI $0.7-2.6$ for asthma). In this study, wheezing in the presence of colds (a symptom not closely linked to asthma diagnosis) was also associated with increased 
rates of pain which suggests that the presence of wheezing per se, regardless of etiology (atopic vs. infectious) may herald increased risk of complications. This cohort also found, for the first time, an increase in mortality associated with wheezing (Hazard ratio $4.295 \% \mathrm{CI}$ 1.0-17.5) but not for asthma (hazard ratio $2.495 \%$ CI 0.6-9.7); although the point estimate for the risk of death associated with asthma, while not statistically significant, was consistent with prior estimates which suggests that a larger sample may have achieved statistical significance. In the Jamaican Sickle Cell Cohort Study, Knight-Madden and colleagues found even larger mortality effects for individuals with active wheezing or medication use within 12 months(defined as current asthma) (Hazard ratio 11.2 95\%CI 2.5-50.6); however, no associations between historical asthma (those who carried a diagnosis but did not have active symptoms or require medication) were found. ${ }^{11}$

\section{vi. Differential diagnosis of wheezing in SCD}

In the individual with SCD who presents with new wheezing, the differential diagnosis varies with age. In young children, one should consider recurrent viral infection, reflux, aspiration and rare causes such as congestive heart failure, tuberculosis, and even cystic fibrosis. Anatomic congenital abnormalities such as vascular ring congenital lobar emphysema, cystic adenomatoid malformation may present with wheeze. In older children and adolescents vocal cord dysfunction may also cause wheezing. Depending on the region, pulmonary mycoses (histoplasmosis, coccidiomycosis) can be an important cause of wheezing in children and adults. For adults, congenital anatomic causes of wheezing are largely replaced by acquired abnormalities including malignancies and non-malignant tumors producing airways compression. In older adults with SCD who smoke, chronic obstructive pulmonary disease is one of the most important causes of recurrent respiratory symptoms. While these causes of wheezing are not specifically associated with SCD, they should be considered before an individual is labeled as having asthma or SCD asthma-likesyndrome.

\section{vii. Evaluation of wheezing in individuals with SCD}

The evaluation of an individual with SCD who reports, or presents with wheezing should begin with a detailed review of exposures, exacerbating factors and other atopic diseases (eczema and rhinitis). Figure 2 provides sample respiratory questions from the National Asthma Education and Prevention Program (NAEPP) that we recommend for the identification of clinically important respiratory symptoms in SCD. A careful family history for atopic disease is also indicated. The physical exam should look for stigmata of atopy including eczema, periorbital puffiness or discoloration (due to venous congestion), allergic salute (a thin horizontal line across the nose caused by frequent rubbing), tonsillar hypertrophy and respiratory findings (wheeze, increased expiratory time and cough). Our group recommends annual pulmonary function testing (spirometry and lung volumes) in all individuals with SCD. In individuals where the clinical picture is unclear (e.g. persistent respiratory symptoms without abnormality of pulmonary function) we recommend spirometry with bronchodilator administration. Bronchoprovocation with methacholine or cold air is not recommended as this has been associated with adverse events ${ }^{30}$ and does not provide diagnostic value for asthma as an overwhelming majority of patients (as high as 
78\% in some series) with SCD exhibit airway hyper responsiveness. ${ }^{31-33}$ Exhaled nitric oxide is also not recommended as part of clinical care. As sleep disordered breathing is associated with pulmonary disease and increased SCD morbidity, we recommend polysomnography for any individual with low daytime oxygen saturation or signs of obstructive sleep apnea. ${ }^{34-57}$

\section{Assessment of wheeze severity}

To classify the severity of pulmonary symptoms we recommend the NAEPP classification system that is used for asthma symptoms (figure 3). Nighttime awakenings due to cough, wheeze or chest tightness are particularly concerning and 2 or more episodes per month should be considered an indication to treat with controller medications (see section viii). Providers should also ask about respiratory symptoms with and without exercise. For students with SCD, a question regarding whether there is wheezing or coughing associated with physical education class is important to include. Respiratory symptoms more frequent than twice per week would be classified as persistent and requiring long term controller medication.

\section{viii. Management of wheezing in SCD: Chronic wheeze}

For individuals with recurrent respiratory symptoms, those who meet criteria for a diagnosis of asthma should be treated in accordance with National Institutes of Health National Asthma Education and Prevention Program guidelines. Optimal management is less clear for individuals who, after a pulmonary evaluation are not given a diagnosis of asthma, yet occasionally manifest wheezing or other symptoms. For persistent wheeze (3 or more times a week on a regular basis), we recommend treatment with an asthma medicine (bronchodilator with inhaled corticosteroid or leukotriene receptor antagonist) and then follow up to determine the usefulness. For wheeze with exercise, we recommend pretreatment 20 minutes before exercise with bronchodilator and follow up with a history from the patient, parent of physical education teacher to determine usefulness. If neither approach is useful for the symptoms, we recommend a careful re-evaluation to determine the cause of symptoms (with special consideration of rare causes and pulmonary mycoses) as well as making sure that the treatments were used thoroughly and correctly.

The recommendations in this section are based upon expert opinion. There are no studies available regarding the use of inhaled steroids or leukotriene receptor antagonists in SCD. There is also a dearth of evidence to guide use of bronchodilators in SCD. Cochrane reviews by Knight-Madden and colleagues have not identified a single article regarding albuterol and SCD. ${ }^{58,59}$

\section{ix. Management of acute episodes of wheezing}

For acute wheezing episodes we recommend administration of an inhaled beta agonist in all cases. We cautiously use systemic glucocorticoids for very short courses 1 to 2 days (initial dose $2 \mathrm{mg} / \mathrm{kg}$ ) as there are associations with rebound pain ${ }^{60-65}$, fat necrosis, ${ }^{66}$ and intracranial hemorrhage. ${ }^{67}$ Below are recommendations for management of acute wheezing in commonly encountered situations: 
- Wheezing in the setting of acute chest syndrome with a prior diagnosis of asthma: we recommend bronchodilator plus short course steroids (single dose dexamethasone $0.3-0.6 \mathrm{mg} / \mathrm{kg}$-max $10 \mathrm{mg}$ or short course prednisone/prednisolone $2 \mathrm{mg} / \mathrm{kg}$-max $60 \mathrm{mg}$ for up to 3 days).

- Wheezing in the setting of acute chest syndrome without a prior diagnosis of asthma: Perform a careful history for atopic disease that would suggest undiagnosed asthma (if there is high suspicion for asthma follow recommendations above). If there is low suspicion for asthma we recommend bronchodilators plus a single dose of prednisone/prednisolone $(2 \mathrm{mg} / \mathrm{kg}$-max $60 \mathrm{mg})$ with a re-evaluation daily for the need to continue steroids.

- Acute wheezing without acute chest syndrome with a prior diagnosis of asthma: we recommend bronchodilator administration with a short course of steroids (single dose dexamethasone $0.3-0.6 \mathrm{mg} / \mathrm{kg}$-max $10 \mathrm{mg}$ or short course prednisone/ prednisolone $2 \mathrm{mg} / \mathrm{kg}$-max $60 \mathrm{mg}$ for up to 3 days) for individuals who do not immediately improve with bronchodilators. For individuals who are not taking an asthma controller medication, we strongly consider initiating treatment at that time (inhaled corticosteroid or leukotriene receptor antagonist). We favor single dose prednisone/prednisolone over dexamethasone for milder cases of wheezing as we have not experienced any rebound pain or noticeable adverse events with single dose prednisone.

- Acute wheezing without acute chest syndrome and without a prior diagnosis of asthma: Perform a careful history for atopic disease that would suggest undiagnosed asthma (if there is high suspicion for asthma follow recommendations above). If there is low suspicion for asthma we recommend bronchodilators plus a single dose of prednisone/prednisolone $(2 \mathrm{mg} / \mathrm{kg}$-max $60 \mathrm{mg})$ with a re-evaluation daily for the need to continue steroids. The patient should be discharged with a prescription for bronchodilator.

\section{$x$. When to refer to an asthma specialist}

We recommend referral to an asthma specialist in any situation where the patient exhibits recurrent pulmonary symptoms (wheeze, cough, chest tightness, even dyspnea on exertion), multiple ACS episodes or a single ACS episode that requires intubation. Referral to an asthma specialist is also recommended for individuals who carry a diagnosis of asthma and their symptoms are not easily controlled with standard controller medicines (inhaled corticosteroids at low or medium dose, oral leukotriene receptor antagonists). Patients who require high dose inhaled steroids or long acting beta agonist combination medications (NAEPP treatment level 3 or greater - figure 4) should be referred for pulmonary evaluation. Depending on location it may be difficult to find an asthma specialist who has experience with SCD. Asthma specialists who do not have prior experience with SCD are usually sufficient, as the goals of care are the same (to progressively step up asthma therapy until symptoms are adequately controlled). In this situation it is important to communicate to the asthma specialist that while definitive evidence is lacking, because of the excellent 
safety profile of most asthma control medications providers should not withhold asthma treatments for fear of exacerbating SCD.

\section{xi. Conclusion}

Wheezing is common in SCD and in some individuals represents an intrinsic component of SCD related lung disease rather than asthma. Regardless of the etiology, individuals with SCD and with recurrent wheezing are at increased risk for subsequent morbidity and premature mortality. We believe Individuals that acutely wheeze and have respiratory symptoms should be managed with a beta agonist and short term treatment of oral steroids, typically less than 3 days to attenuate rebound vaso-occlusive disease. For those that wheeze and have a history or examination associated with atopy, we consider asthma treatment and monitoring per NHLBI asthma guidelines. Prospective SCD-specific clinical trials will be necessary to address whether anti-inflammatory asthma therapies (leukotriene antagonists, inhaled corticosteroids) can safely mitigate the sequelae of wheezing in SCD.

\section{References}

1. Murray, JF.; Mason, RJ. Murray and Nadel's textbook of respiratory medicine. 5. Philadelphia: Saunders/Elsevier; 2010.

2. Hassell KL. Population estimates of sickle cell disease in the U.S. Am J Prev Med. Apr; $201038(4$ Suppl):S512-521. [PubMed: 20331952]

3. http://www.nhlbi.nih.gov/guidelines/asthma/

4. Jaiyesimi O, Kasem M. Acute chest syndrome in Omani children with sickle cell disease: epidemiology and clinical profile. Ann Trop Paediatr. Sep; 2007 27(3):193-199. [PubMed: 17716447]

5. Crawford MW, Speakman M, Carver ED, Kim PC. Acute chest syndrome shows a predilection for basal lung regions on the side of upper abdominal surgery. Can J Anaesth. Aug-Sep;2004 51(7): 707-711. [PubMed: 15310640]

6*. Glassberg J, Spivey JF, Strunk R, Boslaugh S, DeBaun MR. Painful episodes in children with sickle cell disease and asthma are temporally associated with respiratory symptoms. J Pediatr Hematol Oncol. Aug; 2006 28(8):481-485. While this was a retrospective study, the findings of this article were important because the authors demonstrated that, after adjusting for the presence of respiratory symptoms, carrying a diagnosis of asthma was associated with smaller increases in morbidity than previously estimated. The presence of wheezing, regardless of whether the individual carried a diagnosis of asthma was associated with substantial increases in SCD morbidity. [PubMed: 16912587]

7. Glassberg JA, Chow A, Wisnivesky J, Hoffman R, Debaun MR, Richardson LD. Wheezing and asthma are independent risk factors for increased sickle cell disease morbidity. Br J Haematol. Sep 12.2012

8. Poulter EY, Truszkowski P, Thompson AA, Liem RI. Acute chest syndrome is associated with history of asthma in hemoglobin SC disease. Pediatr Blood Cancer. Aug; 2011 57(2):289-293. [PubMed: 21671365]

9. Strouse JJ, Reller ME, Bundy DG, et al. Severe pandemic H1N1 and seasonal influenza in children and young adults with sickle cell disease. Blood. Nov 4; 2010 116(18):3431-3434. [PubMed: 20656929]

10. Knight-Madden JM, Forrester TS, Lewis NA, Greenough A. Asthma in children with sickle cell disease and its association with acute chest syndrome. Thorax. Mar; 2005 60(3):206-210. [PubMed: 15741436]

11**. Knight-Madden JM, Barton-Gooden A, Weaver SR, Reid M, Greenough A. Mortality, asthma, smoking and acute chest syndrome in young adults with sickle cell disease. Lung. Feb; 2013 191(1):95-100. This prospective cohort also stratified their analyses to identify individuals with 
asthma who had active recurrent wheezing. Presence of active pulmonary symptoms was associated with dramatically increased mortality (hazard ratio 11.2, 95\% CI 2.5-50.6). [PubMed: 23149803]

12. Jacob E, Sockrider MM, Dinu M, Acosta M, Mueller BU. Respiratory symptoms and acute painful episodes in sickle cell disease. J Pediatr Oncol Nurs. Jan-Feb;2010 27(1):33-39. [PubMed: 20038672]

13. Field JJ, Stocks J, Kirkham FJ, et al. Airway hyperresponsiveness in children with sickle cell anemia. Chest. Mar; 2011 139(3):563-568. [PubMed: 20724735]

14. Cohen RT, Madadi A, Blinder MA, Debaun MR, Strunk RC, Field JJ. Recurrent, severe wheezing is associated with morbidity and mortality in adults with sickle cell disease. Am J Hematol. Jun 14.2011

15. Field JJ, DeBaun MR. Asthma and sickle cell disease: two distinct diseases or part of the same process? Hematology Am Soc Hematol Educ Program. 2009:45-53. [PubMed: 20008181]

16. Pritchard KA Jr, Ou J, Ou Z, et al. Hypoxia-induced acute lung injury in murine models of sickle cell disease. Am J Physiol Lung Cell Mol Physiol. Apr; 2004 286(4):L705-714. [PubMed: 12972407]

17. Pritchard KA, Feroah TR, Nandedkar SD, et al. Effects of Experimental Asthma on Inflammation and Lung Mechanics in Sickle Cell Mice. Am J Respir Cell Mol Biol. Oct 27.2011

18. Anim SO, Strunk RC, DeBaun MR. Asthma morbidity and treatment in children with sickle cell disease. Expert Rev Respir Med. Oct; 2011 5(5):635-645. [PubMed: 21955234]

19. Bernaudin F, Strunk RC, Kamdem A, et al. Asthma is associated with acute chest syndrome, but not with an increased rate of hospitalization for pain among children in France with sickle cell anemia: a retrospective cohort study. Haematologica. Dec; 2008 93(12):1917-1918. [PubMed: 18815195]

20. Boyd JH, Macklin EA, Strunk RC, DeBaun MR. Asthma is associated with increased mortality in individuals with sickle cell anemia. Haematologica. Aug; 2007 92(8):1115-1118. [PubMed: 17650441]

21. Boyd JH, Macklin EA, Strunk RC, DeBaun MR. Asthma is associated with acute chest syndrome and pain in children with sickle cell anemia. Blood. Nov 1; 2006 108(9):2923-2927. [PubMed: 16690969]

22. Boyd JH, Moinuddin A, Strunk RC, DeBaun MR. Asthma and acute chest in sickle-cell disease. Pediatr Pulmonol. Sep; 2004 38(3):229-232. [PubMed: 15274102]

23. Field JJ, Horst J, Strunk RC, White FV, DeBaun MR. Death due to asthma in two adolescents with sickle cell disease. Pediatr Blood Cancer. Mar; 2011 56(3):454-457. [PubMed: 21113938]

24. Field JJ, Macklin EA, Yan Y, Strunk RC, DeBaun MR. Sibling history of asthma is a risk factor for pain in children with sickle cell anemia. Am J Hematol. Nov; 2008 83(11):855-857. [PubMed: 18819094]

25. Frei-Jones MJ, Field JJ, DeBaun MR. Risk factors for hospital readmission within 30 days: a new quality measure for children with sickle cell disease. Pediatr Blood Cancer. Apr; 2009 52(4):481485. [PubMed: 19058209]

26. McClish DK, Penberthy LT, Bovbjerg VE, et al. Health related quality of life in sickle cell patients: the PiSCES project. Health Qual Life Outcomes. 2005; 3:50. [PubMed: 16129027]

27. Nordness ME, Lynn J, Zacharisen MC, Scott PJ, Kelly KJ. Asthma is a risk factor for acute chest syndrome and cerebral vascular accidents in children with sickle cell disease. Clin Mol Allergy. Jan 21.2005 3(1):2. [PubMed: 15663785]

28. Sylvester KP, Patey RA, Broughton S, et al. Temporal relationship of asthma to acute chest syndrome in sickle cell disease. Pediatr Pulmonol. Feb; 2007 42(2):103-106. [PubMed: 17186507]

29. Cohen RT, Madadi A, Blinder MA, DeBaun MR, Strunk RC, Field JJ. Recurrent, severe wheezing is associated with morbidity and mortality in adults with sickle cell disease. Am J Hematol. Sep; 2011 86(9):756-761. [PubMed: 21809369]

30. Knight-Perry JE, Field JJ, Debaun MR, Stocks J, Kirkby J, Strunk RC. Hospital admission for acute painful episode following methacholine challenge in an adolescent with sickle cell disease. Pediatr Pulmonol. Jul; 2009 44(7):728-730. [PubMed: 19504562] 
31. Leong MA, Dampier C, Varlotta L, Allen JL. Airway hyperreactivity in children with sickle cell disease. J Pediatr. Aug; 1997 131(2):278-283. [PubMed: 9290616]

32. Ozbek OY, Malbora B, Sen N, Yazici AC, Ozyurek E, Ozbek N. Airway hyperreactivity detected by methacholine challenge in children with sickle cell disease. Pediatr Pulmonol. Dec; 2007 42(12):1187-1192. [PubMed: 17960821]

33. Sen N, Kozanoglu I, Karatasli M, Ermis H, Boga C, Eyuboglu FO. Pulmonary function and airway hyperresponsiveness in adults with sickle cell disease. Lung. May-Jun;2009 187(3):195-200. [PubMed: 19301068]

34. Brooks LJ, Koziol SM, Chiarucci KM, Berman BW. Does sleep-disordered breathing contribute to the clinical severity of sickle cell anemia? J Pediatr Hematol Oncol. May; 1996 18(2):135-139. [PubMed: 8846124]

35. Castele RJ, Strohl KP, Chester CS, Brittenham GM, Harris JW. Oxygen saturation with sleep in patients with sickle cell disease. Arch Intern Med. Apr; 1986 146(4):722-725. [PubMed: 3963954]

36. D'Aloya N. Sleep related upper airway obstruction and hypoxaemia in sickle cell disease. Arch Dis Child. May.1993 68(5):715. [PubMed: 8323348]

37. Daniel LC, Grant M, Kothare SV, Dampier C, Barakat LP. Sleep patterns in pediatric sickle cell disease. Pediatr Blood Cancer. Sep; 2010 55(3):501-507. [PubMed: 20658622]

38. Goldstein NA, Keller R, Rey K, et al. Sleep-disordered breathing and transcranial Dopplers in sickle cell disease. Arch Otolaryngol Head Neck Surg. Dec; 2011 137(12):1263-1268. [PubMed: 22183909]

39. Hargrave DR, Wade A, Evans JP, Hewes DK, Kirkham FJ. Nocturnal oxygen saturation and painful sickle cell crises in children. Blood. Feb 1; 2003 101(3):846-848. [PubMed: 12393400]

40. Hollocks MJ, Kok TB, Kirkham FJ, et al. Nocturnal oxygen desaturation and disordered sleep as a potential factor in executive dysfunction in sickle cell anemia. J Int Neuropsychol Soc. Jan; 2012 18(1):168-173. [PubMed: 22114954]

41. Kaleyias J, Mostofi N, Grant M, et al. Severity of obstructive sleep apnea in children with sickle cell disease. J Pediatr Hematol Oncol. Sep; 2008 30(9):659-665. [PubMed: 18776757]

42. Kemp JS. Obstructive sleep apnea and sickle cell disease. J Pediatr Hematol Oncol. May; 1996 18(2):104-105. [PubMed: 8846119]

43. Kirkham FJ, Hewes DK, Prengler M, Wade A, Lane R, Evans JP. Nocturnal hypoxaemia and central-nervous-system events in sickle-cell disease. Lancet. May 26; 2001 357(9269):1656-1659. [PubMed: 11425370]

44. Maddern BR, Reed HT, Ohene-Frempong K, Beckerman RC. Obstructive sleep apnea syndrome in sickle cell disease. The Annals of otology, rhinology, and laryngology. Mar; 1989 98(3):174-178.

45. Needleman JP, Franco ME, Varlotta L, et al. Mechanisms of nocturnal oxyhemoglobin desaturation in children and adolescents with sickle cell disease. Pediatr Pulmonol. Dec; 1999 28(6):418-422. [PubMed: 10587416]

46. Okoli K, Irani F, Horvath W. Pathophysiologic considerations for the interactions between obstructive sleep apnea and sickle hemoglobinopathies. Med Hypotheses. May; 2009 72(5):578580. [PubMed: 19138828]

47. Robertson PL, Aldrich MS, Hanash SM, Goldstein GW. Stroke associated with obstructive sleep apnea in a child with sickle cell anemia. Ann Neurol. Jun; 1988 23(6):614-616. [PubMed: 3408243]

48. Rogers VE, Lewin DS, Winnie GB, Geiger-Brown J. Polysomnographic characteristics of a referred sample of children with sickle cell disease. Journal of clinical sleep medicine : JCSM : official publication of the American Academy of Sleep Medicine. Aug 15; 2010 6(4):374-381. [PubMed: 20726287]

49. Rogers VE, Marcus CL, Jawad AF, et al. Periodic limb movements and disrupted sleep in children with sickle cell disease. Sleep. Jul; 2011 34(7):899-908. [PubMed: 21731140]

50. Salles C, Ramos RT, Daltro C, Barral A, Marinho JM, Matos MA. Prevalence of obstructive sleep apnea in children and adolescents with sickle cell anemia. J Bras Pneumol. Nov; 2009 35(11): 1075-1083. [PubMed: 20011842] 
51. Salles C, Ramos RT, Daltro C, Nascimento VM, Matos MA. Association between adenotonsillar hypertrophy, tonsillitis and painful crises in sickle cell disease. J Pediatr (Rio J). May-Jun;2009 85(3):249-253. [PubMed: 19492171]

52. Samuels MP, Stebbens VA, Davies SC, Picton-Jones E, Southall DP. Sleep related upper airway obstruction and hypoxaemia in sickle cell disease. Arch Dis Child. Jul; 1992 67(7):925-929.

[PubMed: 1308102]

53. Sidman JD, Fry TL. Exacerbation of sickle cell disease by obstructive sleep apnea. Arch Otolaryngol Head Neck Surg. Aug; 1988 114(8):916-917. [PubMed: 3390338]

54. Spivey JF, Uong EC, Strunk R, Boslaugh SE, DeBaun MR. Low daytime pulse oximetry reading is associated with nocturnal desaturation and obstructive sleep apnea in children with sickle cell anemia. Pediatr Blood Cancer. Feb; 2008 50(2):359-362. [PubMed: 17072857]

55. Tripathi A, Jerrell JM, Stallworth JR. Cost-effectiveness of adenotonsillectomy in reducing obstructive sleep apnea, cerebrovascular ischemia, vaso-occlusive pain, and ACS episodes in pediatric sickle cell disease. Ann Hematol. Feb; 2011 90(2):145-150. [PubMed: 20714723]

56. Valrie CR, Gil KM, Redding-Lallinger R, Daeschner C. Brief report: sleep in children with sickle cell disease: an analysis of daily diaries utilizing multilevel models. J Pediatr Psychol. Aug; 2007 32(7):857-861. [PubMed: 17400602]

57. Warrier R, Chauhan A, Athale U. Tonsillectomy and adenoidectomy for obstructive sleep apnea in sickle cell anemia. Indian J Pediatr. Jun; 2010 77(6):669-672. [PubMed: 20532682]

58. Knight-Madden JA, Hambleton IR. Inhaled bronchodilators for acute chest syndrome in people with sickle cell disease. Cochrane Database Syst Rev. 2003; (3):CD003733. [PubMed: 12917983]

59. Knight-Madden JM, Hambleton IR. Inhaled bronchodilators for acute chest syndrome in people with sickle cell disease. Cochrane Database Syst Rev. 2012; 7:CD003733. [PubMed: 22786487]

60. Couillard S, Benkerrou M, Girot R, Brousse V, Ferster A, Bader-Meunier B. Steroid treatment in children with sickle-cell disease. Haematologica. Mar; 2007 92(3):425-426. [PubMed: 17339198]

61. Darbari DS, Castro O, Taylor JGt, et al. Severe vaso-occlusive episodes associated with use of systemic corticosteroids in patients with sickle cell disease. J Natl Med Assoc. Aug; 2008 100(8): 948-951. [PubMed: 18717146]

62. Griffin TC, McIntire D, Buchanan GR. High-dose intravenous methylprednisolone therapy for pain in children and adolescents with sickle cell disease. N Engl J Med. Mar 17; 1994 330(11):733737. [PubMed: 8107739]

63. Isakoff MS, Lillo JA, Hagstrom JN. A single-institution experience with treatment of severe acute chest syndrome: lack of rebound pain with dexamethasone plus transfusion therapy. J Pediatr Hematol Oncol. Apr; 2008 30(4):322-325. [PubMed: 18391705]

64. Sobota A, Graham DA, Heeney MM, Neufeld EJ. Corticosteroids for acute chest syndrome in children with sickle cell disease: variation in use and association with length of stay and readmission. Am J Hematol. Jan; 2010 85(1):24-28. [PubMed: 19957348]

65. Strouse JJ, Takemoto CM, Keefer JR, Kato GJ, Casella JF. Corticosteroids and increased risk of readmission after acute chest syndrome in children with sickle cell disease. Pediatr Blood Cancer. May; 2008 50(5):1006-1012. [PubMed: 17849474]

66. Johnson K, Stastny JF, Rucknagel DL. Fat embolism syndrome associated with asthma and sickle cell-beta(+)-thalassemia. Am J Hematol. Aug; 1994 46(4):354-357. [PubMed: 8037190]

67. Strouse JJ, Hulbert ML, DeBaun MR, Jordan LC, Casella JF. Primary hemorrhagic stroke in children with sickle cell disease is associated with recent transfusion and use of corticosteroids. Pediatrics. Nov; 2006 118(5):1916-1924. [PubMed: 17079562] 


\section{Key Points}

- Wheezing is common in SCD and in some individuals represents an intrinsic component of SCD related lung disease rather than asthma.

- Regardless of the etiology, individuals with SCD and with recurrent wheezing are at increased risk for subsequent morbidity and premature mortality.

- Individuals that acutely wheeze and have respiratory symptoms should be managed with a beta agonist and short term treatment of oral steroids, typically less than 3 days to attenuate rebound vaso-occlusive disease.

- For those that wheeze and have a history or examination associated with atopy, we consider asthma treatment and monitoring per NHLBI asthma guidelines.

Recent articles of special importance from the reference list below (single star * indicates special importance, $* *$ indicates outstanding): 


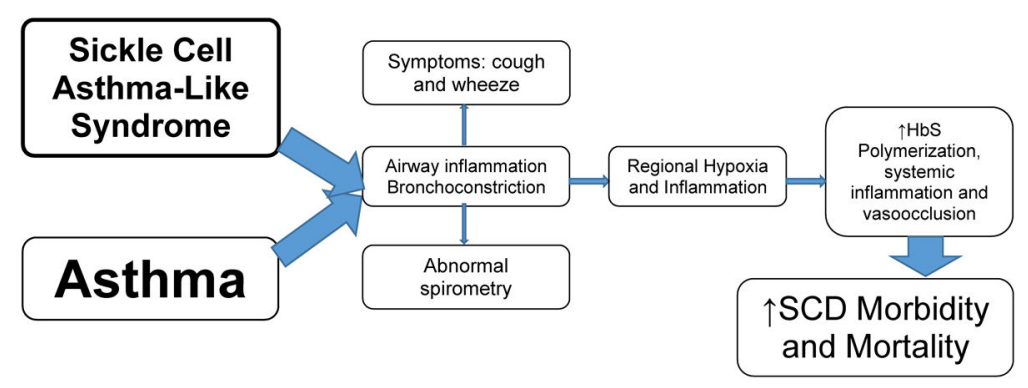

Figure 1.

Conceptual model to explain the association between wheezing and SCD mortality. Wheezing is common in SCD and in some individuals represents an intrinsic component of SCD related lung disease rather than asthma. Both etiologies of wheeze likely create ventilation-perfusion mismatch which increases regional hypoxia, red cell sickling, membrane damage and inflammation leading to increased systemic complications of SCD. 


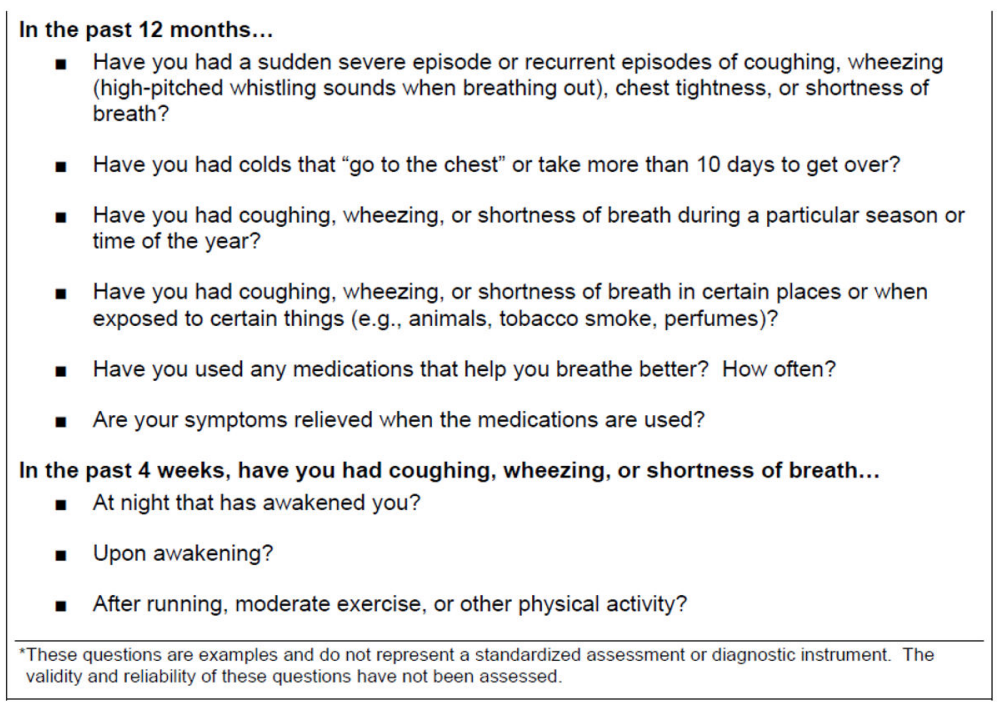

Figure 2.

Sample questions which may assist in the identification of clinically important respiratory symptoms in individuals with SCD.

A yes to any one question indicates that clinically significant respiratory symptoms are present and that further evaluation and treatment are indicated. Adapted from the National Asthma Education and Prevention Program (NAEPP) 2007 guidelines (http:// www.nhlbi.nih.gov/guidelines/asthma/). 
- Classifying severity in children who are not currently taking long-term control medication.

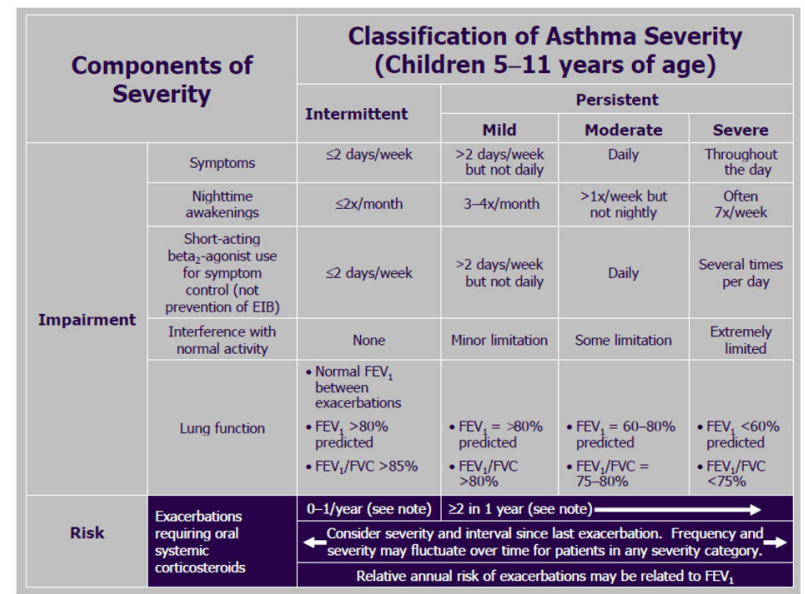

- Level of severity is determined by both impairment and risk. Assess impairment domain by patient's/caregiver's recall of the previous 2-4 weeks and spirometry. Assign severity to the most severe category in which any feature occurs.

- At present, there are inadequate data to correspond frequencies of exacerbations with different levels of asthma severity. In general, more frequent and intense exacerbations (e.g., requiring urgent, unscheduled care, hospitalization, or ICU admission) indicate greater past year may be considered the same as patients who have persistent asthma, even in the absence of impairment levels consistent with persistent asthma.

- Classifying severity in patients after asthma becomes well controlled, by lowest level of treatment required to maintain control.*

\begin{tabular}{|c|c|c|c|c|}
\hline \multirow{4}{*}{$\begin{array}{l}\text { Lowest level of } \\
\text { treatment required } \\
\text { to maintain control } \\
\text { (See figure 4-1b } \\
\text { for treatment steps.) }\end{array}$} & \multicolumn{4}{|c|}{ Classification of Asthma Severity } \\
\hline & Intermittent & \multicolumn{3}{|c|}{ Persistent } \\
\hline & & Mild & Moderate & Severe \\
\hline & Step 1 & Step 2 & Step 3 or 4 & Step 5 or 6 \\
\hline \multicolumn{5}{|c|}{$\begin{array}{l}\text { Key: EIB, exercise-induced bronchospasm; FEV }{ }_{1} \text {, forced expiratory volume in second; FVC, forced vital capacity; ICU, intensive } \\
\text { care unit }\end{array}$} \\
\hline \multicolumn{5}{|c|}{$\begin{array}{l}\text { "Notes: } \\
\text { - For population-based evaluations, clinical research, or characterization of a patient's overall asthma severity after control is achieved } \\
\text { For clinical management, the focus is on monitoring the level of control (See figure 3-5b.), not the level of severity, once treatment is } \\
\text { established. }\end{array}$} \\
\hline
\end{tabular}

Figure 3.

NAEPP schema for classification of asthma severity.

We recommend using the NAEPP schema to classify the severity of symptoms in individuals with SCD who report wheezing cough or shortness of breath regardless of whether or not the patient carries a diagnosis of asthma. The severity of symptoms then dictates the level of treatment which is described in figure 4. Adapted from the National Asthma Education and Prevention Program (NAEPP) 2007 guidelines (http:// www.nhlbi.nih.gov/guidelines/asthma/). 


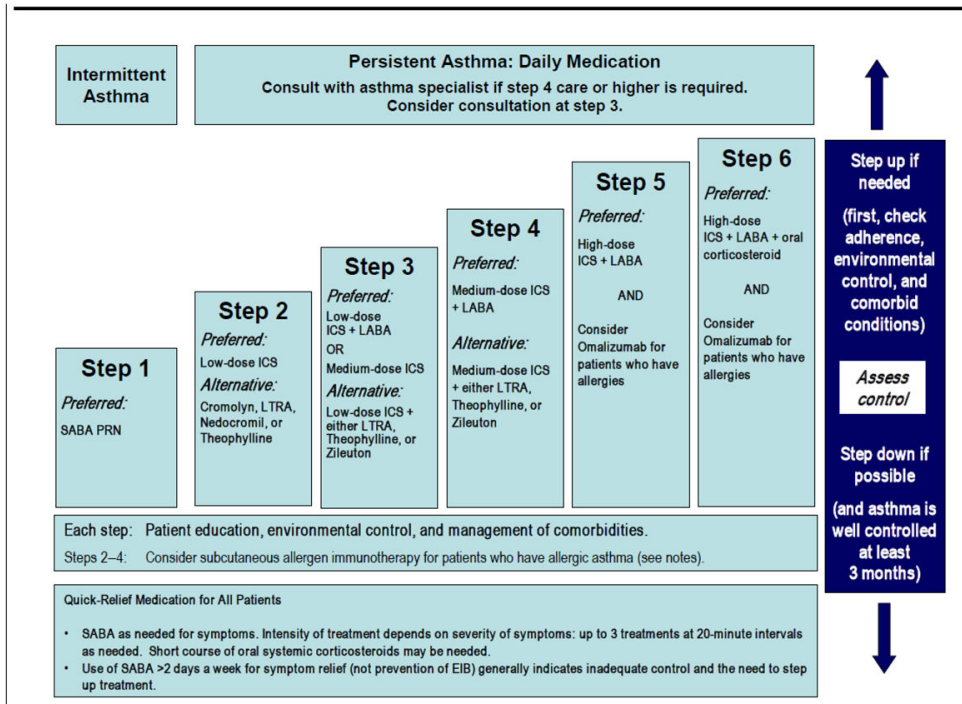

- Key: Alphabetical order is used when more than one treatment option is listed within either preferred or alternative therapy. EIB, exercise-induced bronchospasm; ICS, inhaled corticosteroid; LABA, long-acting inhaled beta ${ }_{2}^{-}$

Notes:

- The stepwise approach is meant to assist, not replace, the clinical decisionmaking required to meet individual patient

needs.

- If alternative treatment is used and response is inadequate, discontinue it and use the preferred treatment before stepping up.

- Zileuton is a less desirable alternative due to limited studies as adjunctive therapy and the need to monitor liver

- In step 6, before oral systemic corticosteroids are introduced, a trial of high-dose ICS + LABA + either LTRA theophylline, or zileuton may be considered, although this approach has not been studied in clinical trials.

- Step 1,2 , and 3 preferred therapies are based on Evidence $A$; step 3 alternative therapy is based on Evidence $A$ for LTRA, Evidence $B$ for theophylline, and Evidence $D$ for zileuton. Step 4 preferred therapy is based on Evidence preferred therapy is based on Evidence B. Step 6 preferred therapy is based on (EPR-2 1997) and Evidence B for omalizumab.

- Immunotherapy for steps 2-4 is based on Evidence B for house-dust mites, animal danders, and pollens; evidence is weak or lacking for molds and cockroaches. Evidence is strongest for immunotherapy with single allergens. The role of allergy in asthma is greater in children than in adults.

- Clinicians who administer immunotherapy or omalizumab should be prepared and equipped to identify and treat anaphylaxis that may occur.

\section{Figure 4.}

NAEPP stepwise management schema.

The level of therapy is dictated by the severity of the patient's symptoms as classified in figure 3. Any patient who requires step 3 or higher should be referred to an asthma specialist. Adapted from the National Asthma Education and Prevention Program (NAEPP) 2007 guidelines (http://www.nhlbi.nih.gov/guidelines/asthma/). 


\section{Table 1}

Prospective studies of wheezing in SCD

\begin{tabular}{|c|c|c|c|c|}
\hline Study (year) & Study design & Sample size & Wheezing definition, prevalence & Ref. \\
\hline Knight-Madden 2005 & Cross section & $\begin{array}{l}80 \text { children with } \\
\text { SCD age } 5-10\end{array}$ & $\begin{array}{l}\text { 'Current asthma' defined as wheeze or prolonged } \\
\text { dry cough within the last } 12 \text { months. Prevalence } \\
=41 \%\end{array}$ & 9 \\
\hline Knight-Madden 2013 & Prospective longitudinal cohort & $\begin{array}{l}75 \text { individuals age } \\
19-27 \text { followed } \\
\text { during a } 10 \text { year } \\
\text { period }\end{array}$ & $\begin{array}{l}\text { 'Current asthma' defined as wheeze within the } \\
\text { last } 12 \text { months or use of asthma medication. } \\
\text { Prevalence } 9 \%\end{array}$ & 10 \\
\hline Jacob 2010 & Cross section & $\begin{array}{l}93 \text { children mean } \\
\text { age } 9.8\end{array}$ & $\begin{array}{l}\text { Wheeze defined by self-report on ISAAC* } \\
\text { survey. Prevalence overall } 29 \% \text {, with colds } 29 \% \text {, } \\
\text { without colds } 23.7 \% \text {, during sleep } 20.4 \%\end{array}$ & 11 \\
\hline Field 2011 & Multi-center prospective cohort & $\begin{array}{l}99 \text { children age } 5.6 \\
\text { to } 19.9 \text { years } \\
\text { referred for } \\
\text { methacholine } \\
\text { challenge }\end{array}$ & $\begin{array}{l}\text { Wheeze defined by ATS-DLD** parent-report. } \\
\text { Prevalence of wheeze } 51 \% \text {, with colds }=51 \% \text {, } \\
\text { without colds } 18 \% \text {, with exercise } 41 \%\end{array}$ & 12 \\
\hline Cohen 2011 & $\begin{array}{l}\text { Prospective longitudinal cohort, } \\
\text { mean follow-up } 2.3 \text { years }\end{array}$ & $\begin{array}{l}114 \text { Adults, mean } \\
\text { age } 31.8\end{array}$ & $\begin{array}{l}\text { Wheeze defined by ATS-DLD** self-report, } \\
\text { prevalence of wheeze } 64 \% \text {, with colds } 61 \% \text {, } \\
\text { without colds } 30 \% \text {, with exercise } 39 \%\end{array}$ & 13 \\
\hline
\end{tabular}

